\title{
ゾル・ゲル法を用いる各種繊維の無電解めっきの前処理
}

\author{
福井大学大学院工学研究科 水囊 満・高木 努・廣坦和正・堀 照夫
}

\section{Sol/gel Pretreatment of Various Fabrics for Electroless Plating}

\author{
Mitsuru Mizuno $^{* 1}$, Tsutomu Takagi ${ }^{* 1}$, Kazumasa Hirogaki ${ }^{* 1}$, and Teruo Hori ${ }^{* 1}$ \\ ${ }^{* 1}$ Fiber Amenity Engineering Course, Graduate School of Engineering, University of Fukui, \\ 3-9-1 Bunkyo, Fukui 910-8057, Japan
}

\begin{abstract}
: 3-aminopropyl triethoxysilane was hydrolyzed in water or water and ethanol mixture for several hours to produce its trihydroxysilane (silanol) derivative. This silanol derivative was then fixed on the surfaces of cotton, vinylon, and oxygen-plasma-pretreated PP and PET fabrics by pad-cure method. The fixation of hydrolyzed APS on the fabrics was confirmed by XPS analysis. APS-fixed fabrics were easily metalized by usual electroless cupper plating. The amount of plated cupper and the electric resistivity of the $\mathrm{Cu}$-plated fabrics were measured. The electric resistivity in the cases of the $\mathrm{Cu}$-plated PP and PET fabrics was kept even after washing.
\end{abstract}

(Received 24 November, 2011 ; Accepted 27 December, 2011)

\section{1. 緒 言}

金属を付与した導電性㵶維は柔軟で軽量という特長が ある.製造法として繊維にあらかじめ導電性材料を瀻維 の紡糸時に練り込む方法と汎用瀻維表面への金属めっき 法がある. 今後, e テキスタイルの発展に伴い, 十分な導 電性と耐久性の高い導電性瀻維が必要とされる [1].

本研究ではシランカップリング剂が水酸基を有する緎 維と強固に結合する $[2]$ ことを利用し, 必要に応じてシラ ンカップリング剂の反応座席を設けるために酸素プラズ マも併用する新しい無電解めっき前処理法を検討した.

酸素プラズマ照射を行うことでポリプロピレン $(\mathrm{PP})$ な どの極性基を有しない高分子に酸素原子を導入できるこ とはすでによく知られている[3]．ポリエステル(PET)で も酸素プラズマ照射により酸素原子の含量が増え, シラ ンカップリング剤の反応基の対象となる可能性がある.

アミノ基を分子末端に有するシランカップリング剂が 纎維に固定できれば, このアミノ基に $\mathrm{Sn} / \mathrm{Pd}$ コロイドな どの無電解めっき用触媒を作用させることで Pd を強固に 結合できる，その後，Pd上に無電解めっきを行うことで 強固なめっき層が形成できると期待できる.

以上の原理で各種織物のシランカップリング剂の固定 を介した耐久性の高い繊維のめっきを行った，瀻維とし ては, 本来十分な水酸基を有し, シランカップリング剤 が反応できる綿，ビニロンの他に，水酸基を有しないか， またはその量が非常に少ないPP 抄よび PET は予め酸素 プラズマで前処理して使用した.

\section{2. 実 験}

\section{1 試料}

シラン化合物としては末端にアミノ基有する3-アミノ プロピルトリエトキシシラン (APS) (信越化学, 図 1 左参 照をを用いた。

布帛の加工に扔いては APS を加水分解し, シラノール タイプに変換したもの(図 1 右)を用いた. シラノール化 合物は-OH 間で一部は縮合し, 高分子化されていると思 われる。詳細は後述する。

繊維材料には綿ブロード(侏色染社)，ビニロン(侏)ク レ提供), ポリプロピレンタフタ PP(侏色染社) およびポ リエチレンテレフタレートタフタ PET(侏色染社)をそれ ぞれ, アセトン, エタノール, 水の各浴に順に浸漬して 洗浄して用いた.

無電解用めっき触媒として市販の $\mathrm{Sn} / \mathrm{Pd}$ コロイド液 OPC-80 キャタリストおよび OPC-SAL-M を, 触媒の活性 剤としてOPC-500 アクセレーターMX-1 を，そして無電<smiles>CO[Si](CCCN)(OC)OC</smiles>

Fig. 1 Silane compound used and its hydrolyzed compound, which may be condensed and polymerized more or less. 
解銅めっき液としてATS-アドカッパー IW-A, IW-M, C を用いた. これらの試薬はいずれも奥野製薬工業(侏)から 購入したものをそのまま用いた.

\section{2 プラズマ前処理}

PPおよびPET布帛については, Yamato 製, Plasma Reactor PR300を用いて酸素プラズマによる前処理を行っ た. 照射は $100 \mathrm{~W}$ の出力で $3 \sim 60$ 秒, 時間を変えて照射 した.

\section{3 シランカップリング剤の反応}

シランカップリング剂の固定原理と工程を図 2 に示し た.エタノール/水(モル比 1:1), または水に溶解させた APS 1\% 溶液を室温で 24〜 48 時間擋拌することで, 加水 分解させ, エトキシ基の部分をシラノール基に変えた. この場合, 生成したシラノール化合物の-OH 基同士が脱 水縮合し, 一部は重合が進むと言われているが, 本研究 では重合の確認は特に行わず, この溶液に各種布帛を浴 比 $1: 100$ で浸漬させた後, 余分な溶液を除去し，25，80 および $130^{\circ} \mathrm{C}$ で 30 分加熱処理することでシラノール化合 物を繊維表面に固定化した。

\section{4 めっき処理}

繊維への銅めっき工程は無電解めっき法で行った。PP と PET 布については酸素プラズマ処理によって表面に酸 素原子を導入したもの, 綿, ビニロンはそのまま 2.3 に示 した方法で加水分解させた APS を固着させた後, めっき 触媒となる $\mathrm{Sn} / \mathrm{Pd}$ 溶液に加工布を浸漬し, 次でアクセレー ター溶液によって Pd を活性させた後, 無電解銅めっきに よって銅めっきを行った。

\section{5 各種分析と物性評価}

\subsection{1 プラズマ照射および APS 固定試料の表面分析}

プラズマ照射前後の PP および PET 繊維の表面を走査 型電子顕微鏡 $(\mathrm{SEM}) \mathrm{S}-2600 \mathrm{H}$ (日立(株))で観察し, X 線光電 子分光法 (XPS) (日本電子(株) を用いて成分の分析を行った.

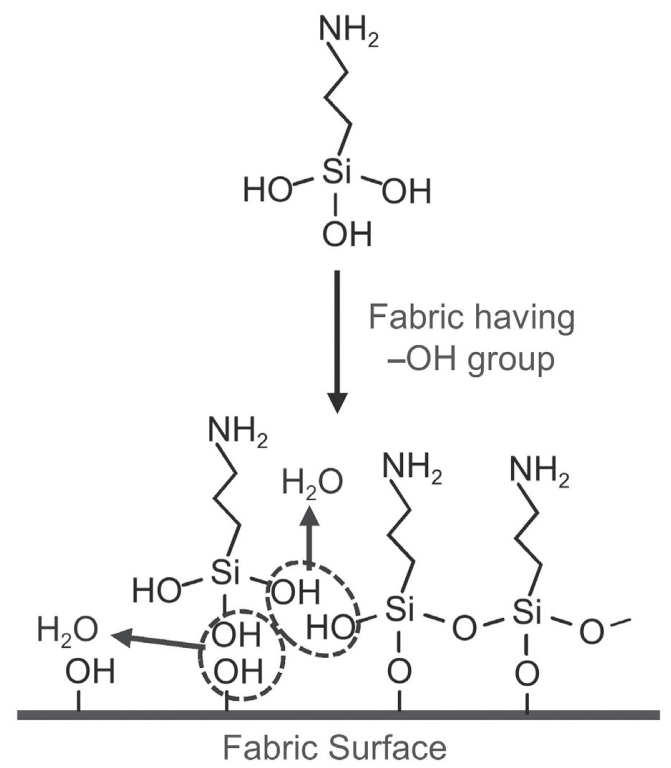

Fig. 2 Mechanism of silanol compound fixation on the surface of fibers having - $\mathrm{OH}$ groups.
いずれの場合も, 酸素プラズマ照射によりどの程度酸素 原子の取り込みが行われているか確認するため元素組成 も調べた。

また, 繊維上での APS の反応および固定は FT-IR (4100 型, 日本電子(株))の ATR 法と上記の XPS で確認した。

\subsection{2 めっき繊維の導電性および耐洗たく性評価}

めっきした布帛の表面抵抗率は Loresta $\mathrm{AP}$ (三菱油化(侏) を用いて, 4 端子法で 5 回以上測定し, その平均值を求め た.

めっき布帛は JIS L 1096 の 103 法に従って 10 回洗たく した. 洗たく後乾燥し, 再度表面抵抗率を測定した.

なお，めっきの密着性についてはJIS H 8504 めっき密 着性試験法のテープ試験法に準じて評価した.

\section{3. 結果と考察}

\section{1 酸素プラズマ処理による PP および PET の改質}

図 3, 図 4 にそれぞれ酸素プラズマ照射前後のPP およ びPET 緎維のXPS スペクトルを示した.PPでは酸素プ ラズマ照射により， $\mathrm{C}-\mathrm{O}$ および $\mathrm{O}=\mathrm{C}-\mathrm{O}$ 結合に基づくピー クが新たに現れ，PETではこのピークが大きくなってい ることが確認され, 酸素原子が取り込まれていることが わかる. ピーク高さから求めた元素比率では, PP では $\mathrm{C}-\mathrm{O}$ および $\mathrm{O}=\mathrm{C}-\mathrm{O}$ 由来の炭素成分がそれぞれ $0.3,0.4$ (恐ら く PP に吸着していた酸素に由来すると思われる)から $4.0 \%$ および $14.6 \%$ 増加した. また, PETでは $\mathrm{C}-\mathrm{O}$ およ び $\mathrm{O}=\mathrm{C}-\mathrm{O}$ 由来の炭素成分は $15.4 \%$ が $22.0 \%, 19.7 \%$ が
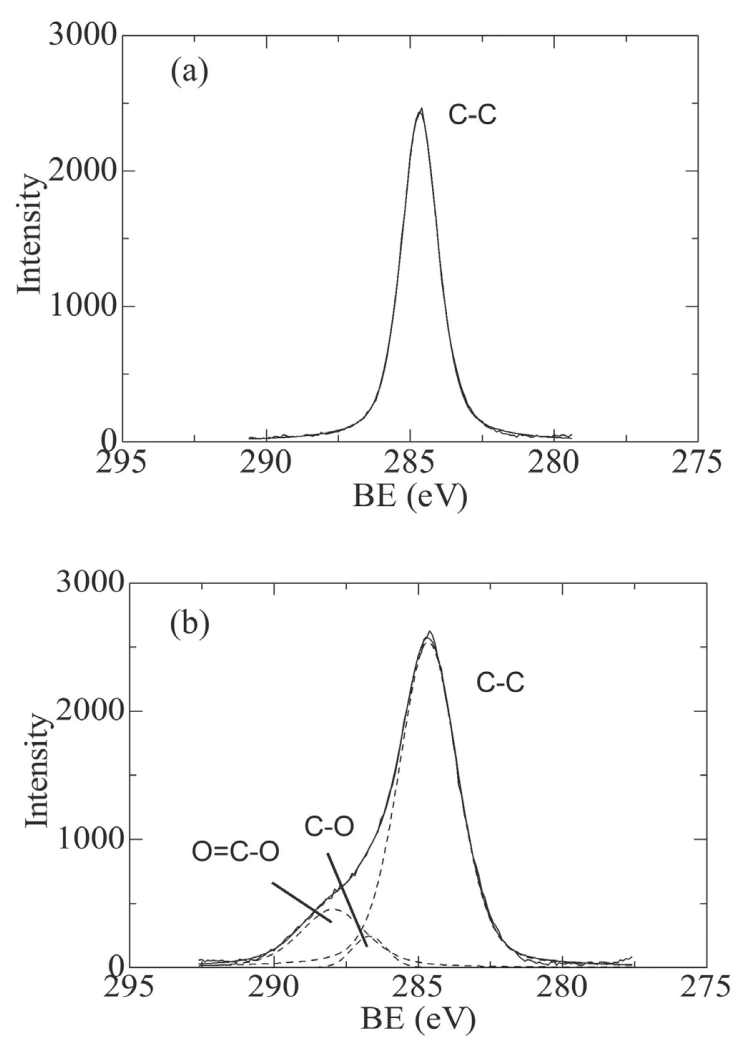

Fig. 3 XPS narrow scan spectrum of untreated, (a) and $\mathrm{O}_{2}$-plasma treated (b) PP fiber. 

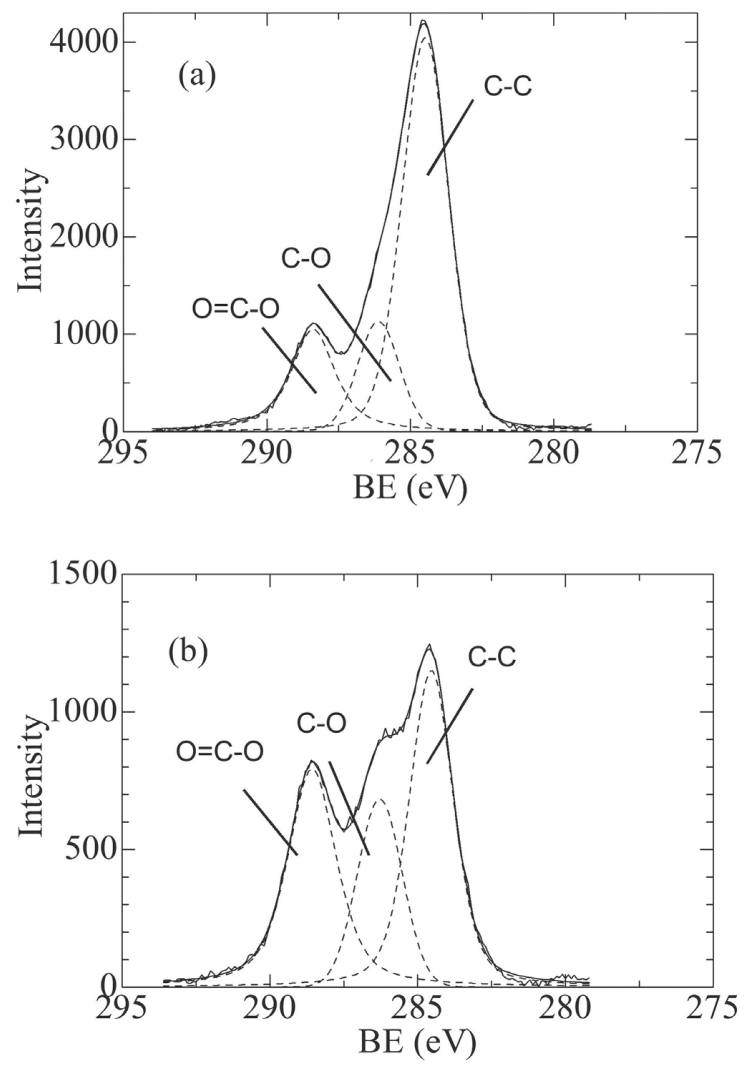

Fig. 4 XPS narrow scan spectrum of untreated, (a) and $\mathrm{O}_{2}$-plasma treated (b) PET fiber.

$35.2 \%$ にまで増加していることが解った．また，SEM 観 察の結果, 繊維の表面の荒れはわずかであった.

\subsection{APS の加水分解・縮合反応の確認}

図 5 に, 2.3 の方法で 24 時間加水分解した APS 溶液に 酸素プラズマ処理したPP 布帛を浸漬し，風乾後，25，80 および $130^{\circ} \mathrm{C} て ゙ 30$ 分熱処理した後の繊維表面を FT-IRの ATR 法(KRS-5 プリズム使用)で測定した結果を示した. $1020 \mathrm{~cm}^{-1}$ に Si-O-Si 伸縮振動に基づく吸収が, また $1590 \mathrm{~cm}^{-1}$ には- $\mathrm{NH}_{2}$ の変角振動に基づく吸収が確認され, APS 加水 分解物が酸素プラズマ処理した PP 布帛と酸素原子を介し て結合していることがわかる[4].48時間加水分解した APS を用いた場合は $1020 \mathrm{~cm}^{-1}$ のピークが若干大きくなっ たが, その他のピークの高さの変化や新しいピークは観 察されなかった.このことから，24〜48 時間程度の熟成 (APS の加水分解) 後は, $25 \sim 130^{\circ} \mathrm{C}$ のいずれの温度でも繊 維と十分反応できる状態に加水分解されていることがわ かった。

\subsection{APS 固定繊維の表面分析}

APS を固定した各布帛を洗浄後, 乾燥し, 加工表面の XPS 分析を行った. 一例として, 酸素プラズマで 30 秒間 前処理し, APS で加工したPPの Wide scanスペクトルを 罒 6 に示す. APS を固定したその他の布帛についても同 様な測定を行い, 元素分析の結果をまとめて表 1 に示し た.

いずれの処理布においても本来の繊維にも存在しない $\mathrm{N}$ および Si 元素が確認されたことから, APS は繊維とシ

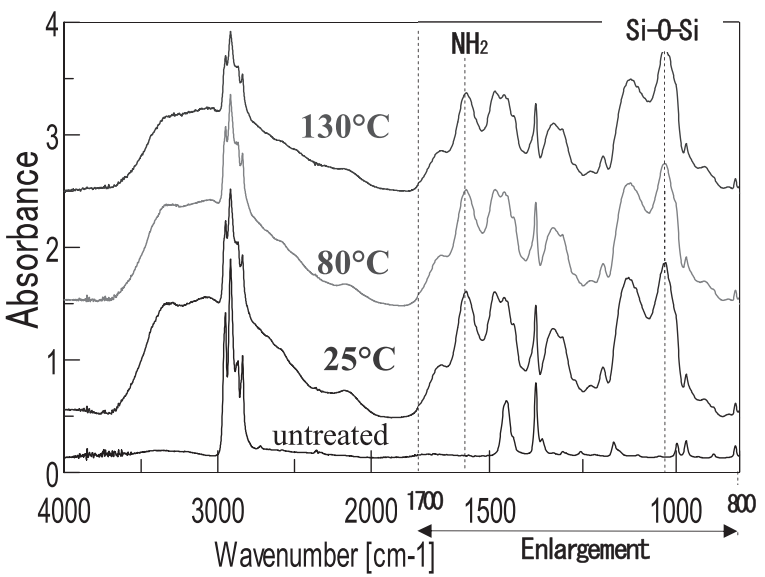

Fig. 5 ATR spectra of 24h hydrolyzed APS reacted PP Fabric. PP fabric was pretreated for $30 \mathrm{~s}$ with $\mathrm{O}_{2}$ Plasma. From the bottom to top, spectra are for untreated and for reaction temperature at 25, 80 and $130^{\circ} \mathrm{C}$, respectively.

ラノール結合により結合しているものと判断した．綿に おいて $\mathrm{N}$ と $\mathrm{Si}$ の存在比が比較的低いのは, 綿の繊維構造 が粗であるため, APS が単繊維内部にまで入り込んでお り, 最表面のみが測定範囲となるXPS では存在比が低く なったものと考えられる.

\section{4 めっき繊維の物性および形態評価}

APS を固定化した後, 2.4 で示した方法により各繊維の

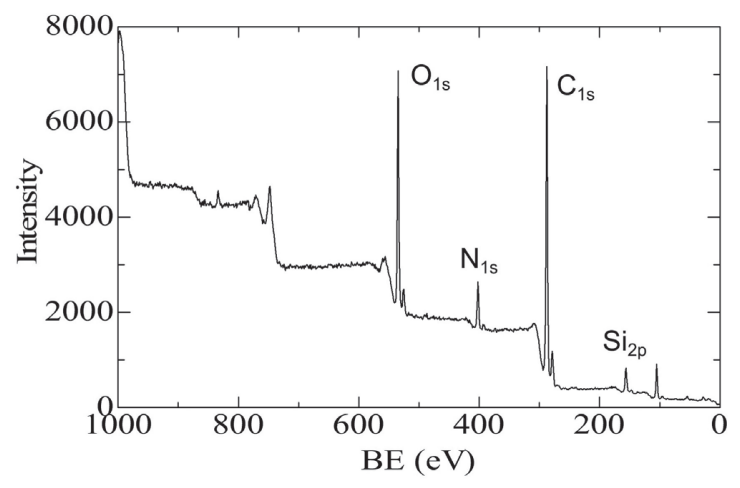

Fig. 6 XPS wide scan spectrum of APS-fixed PP fabric, which was pretreated for $30 \mathrm{~s}$ with $\mathrm{O}_{2}$ plasma.

Table 1 Atomic content of APS-treated fabrics.

\begin{tabular}{cccccc}
\hline \multirow{2}{*}{ Fabric } & \multirow{2}{*}{ Treatment } & \multicolumn{5}{c}{ Atomic content \% } \\
\cline { 3 - 6 } & & $\mathrm{C}$ & $\mathrm{O}$ & $\mathrm{N}$ & $\mathrm{Si}$ \\
\hline PP & untreated $^{*}$ & 93.8 & 5.3 & - & 1.2 \\
& -Plasma $^{\text {a) }}$-APS & 67.5 & 18.9 & 5.2 & 8.4 \\
\hline \multirow{2}{*}{ PET } & untreated & 67.9 & 32.1 & - & - \\
& -Plasma $^{\text {a) }}$-APS & 66.9 & 29.2 & 1.4 & 2.5 \\
\hline \multirow{2}{*}{ cotton } & untreated & 58.7 & 41.3 & - & - \\
& -APS & 62.5 & 35.6 & 0.8 & 1.1 \\
\hline \multirow{2}{*}{ vinylon } & untreated & 75.3 & 24.7 & - & - \\
& -APS & 71.6 & 24.7 & 1.5 & 2.2 \\
\hline
\end{tabular}

a) PP and PET fabrics were pretreated for $30 \mathrm{~s}$ with $\mathrm{O}_{2}$ plasma. 
無電解めっきを行った. 図 7 には未処理 PP, エ夕ノール/ 水および水のみを媒体として APS 処理を行った布帛に対 し, めっき量, 電気抵抗率への影響を示した。左の縦軸 が表面電気抵抗率, 右軸はめっきによる重量増加率を示 す. 棒グラフの左は, 酸素プラズマ処理を $30 \mathrm{~s}$ 行った PP 布帛, 中央がその後エタノール水溶液で APS 処理したも の, 右が水溶液で APS 処理したものである. エタノール 水溶液は APS の良溶媒として用いられているが, 本研究 結果ではむしろ水溶液を用いた方が表面抵抗率も低く めっき性が良いことがわかる.

酸素プラズマ処理後めっきした布帛では, めっき量は 多いが, 表面抵抗率は高い. また, テープ試験の結果で は酸素プラズマ処理後めっきしたPP のめっき密着性は十 分でなく, 酸素プラズマ処理後, 水系でめっきした PP 布 帛ではほとんどめっきは剥がれなかった(図 8 参照).

酸素プラズマ処理後めっきしたPP 布帛では, 表面に酸 素原子が取り达まれ, 表面自由エネルギーが低下して触 媒が繊維表面に付着されやすくなり, めっき量が増した ものと思われるが, 触媒の吸着は単なる物理吸着のため, 容易にめっきが剥がれたものと考えている.これに対し， 酸素プラズマ処理後, APS 処理したものでは(溶媒がエ夕 ノール系と水系の両方とも)めっき試料のテープ試験での 銅の剥離はなく, 電気抵抗率も低い值を示した.このこ とから, 酸素プラズマ処理後 APS 処理することでAPS は 繊維と共有結合で結合し, この分子の末端アミノ基に強

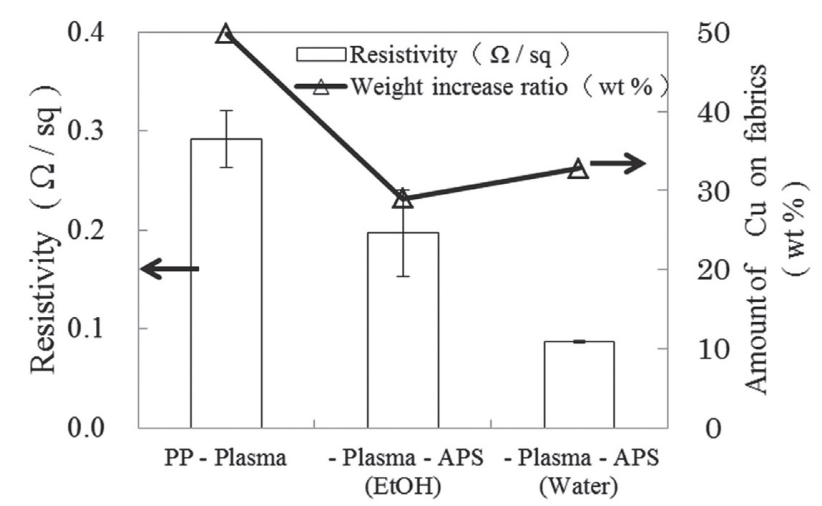

Fig. 7 Amount of $\mathrm{Cu}$ plating and resistivity of $\mathrm{Cu}-$ plated PP fabrics after plasma and APS treatments.
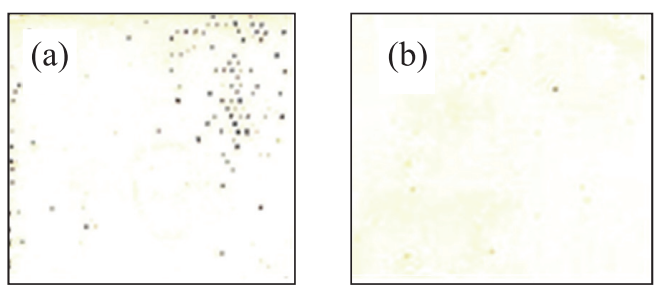

Fig. 8 Peeling test of $\mathrm{Cu}$-plated PP fabrics. (a)only $\mathrm{O}_{2}$ plasma treated PP : significant amount of $\mathrm{Cu}$ was peeled off and (b) $\mathrm{O}_{2}$-plasma and then APS treated PP : almost no $\mathrm{Cu}$ peeled off after peeling test.
固にPd が配位したため, 高い密着性の銅めっきができた ものと考えられる.

PET 布帛についての結果を図 9 に示す。試料はめっき の前処理として, 左から前処理なし, プラズマ処理 $60 \mathrm{~s}$ のみ, エ夕ノール/水系で APS 処理, プラズマ処理 60s 後 エ夕ノール/水系で APS 処理, 水系で APS 処理, プラズ マ処理後水系で APS 処理したものを示す.

めっきした PET 布に対してめっき密着性をテープ試験 によって評価した結果, PP とほぼ同じょうに, セロハン テープにはほとんど銅が付着せず, 高い密着性を有して いた。一方, APS 処理後にめっきした試料はめっき量が 抵抗率に依存しており, プラズマ処理によってめっき量 が増加していることがわかった.

前処理によるめっき試料断面の変化を SEMによって観 察した。その結果の一例を図 10 に示した。左の画像が酸 素プラズマ処理後めっきしたPP 布, 右が酸素プラズマ後 さらに APS 処理してめっきしたPP布帛の断面である.

白く見える部分は銅めっきされた部分で, 両者に大きな 差は見えないが, 右のめっき部は左より幾分厚く見える. 酸素プラズマと APS 処理によって繊維表面に均一に APS が固定されたためと考えられる.

PET 布帛においても類似の観察ができた(写真は省略). 酸素プラズマ照射し, APS で処理した場合, めっき層は 厚く, フィラメント 1 本 1 本が斑なく均一にめっきされ ていることがわかる.

次に, 綿, ビニロン布帛について, APS 未処理および

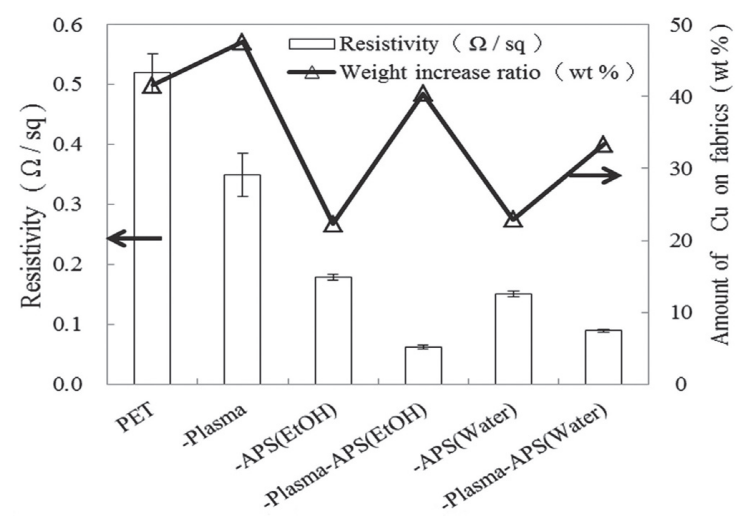

Fig. 9 Amount of $\mathrm{Cu}$ plating and resistivity of $\mathrm{Cu}$ plated PET fabrics.

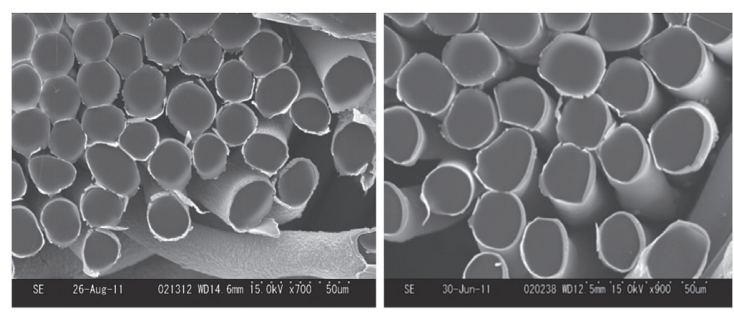

Fig. 10 SEM images of cross section of $\mathrm{Cu}$ plated PP fabric. Left: $\mathrm{O}_{2}$-plasma pretreated and $\mathrm{Cu}$ plated. Right: $\mathrm{O}_{2}$-plasma pretreated, APSfixed and $\mathrm{Cu}$ plated. 
APS 処理した場合について, めっき量と表面抵抗率への 影響を表 2 にまとめた. APS をエ夕ノール/水系または水 系で作用させた場合, 綿およびビニロンの両布帛におい て, 未処理布を直接めっきした場合に比べ, めっき量は 2 倍以上増加し, 表面抵抗率も大きく低下しており, APS による前処理がめっきに非常に効果的であることがわか る.

また, APS 処理後にめっきした試料はテープ剥離試験 で繊維くずの付着は見られたが, 銅の剥離は全く確認さ れなかった.さらに, この試料の断面の SEM 観察で繊維 一本一本にめっきされていることが分かる.これは先程 の PP, PET 布の場合と同様, APS 処理によって繊維表面 に均一にAPS が固定されたためと考えられる.

\section{5 めっき繊維の洗たく耐久性}

PP, 綿, ビニロン布帛について, 洗たく 10 回による耐 久性を評価した. 10 回洗たく後のめっき表面の写真を図 12 に示す.いずれも 10 回洗たくしたとは思えないほど めっきの剥離が少ない. しかし, 表面抵抗は(a)では洗た く前が $0.29 \Omega / \mathrm{sq}$ であったものが, $5.04 \Omega / \mathrm{sq}$ に（b)では 0.087 から $0.41 \Omega / \mathrm{sq}$ に，(c)では 0.38 から $6.61 \Omega / \mathrm{sq}$ に，ま た (d)では 0.15 から $14.9 \Omega / s q$ に上昇している. 酸素プラ ズマ処理後 APS を固定化してめっきしたPP布帛では洗 たく後 (b) も $0.41 \Omega / \mathrm{m}$ と低い值を示し, 高い導電性を維持 していることがわかる. ここでは写真は示さないが, PET 布帛についてもPPの場合と同様に酸素プラズマ処理後 APS 固定化してめっきしたものは高い洗たく耐久性を示 した.

綿やビニロン布帛で 10 回洗たく後の表面低効率の上昇 が大きいのは, 纎維が親水性のため洗濯中に大きく膨潤 し, めっき層に亀裂が入り, 一部めっき剥がれが起きた

Table 2 Amount of $\mathrm{Cu}$ and electric resistivity of cotton and vinylon fabrics treated by APS and then plated by $\mathrm{Cu}$.

\begin{tabular}{lcccccc}
\hline & \multicolumn{2}{c}{ untreated } & \multicolumn{2}{c}{$\begin{array}{c}\text { APS-treated } \\
\text { in EtOH }\end{array}$} & \multicolumn{2}{c}{$\begin{array}{c}\text { APS-treated } \\
\text { in } \mathrm{H}_{2} \mathrm{O}\end{array}$} \\
\cline { 2 - 7 } fabric & $\mathrm{Cu}^{\mathrm{a})}$ & $\mathrm{R}^{\mathrm{b})}$ & $\mathrm{Cu}^{\mathrm{a})}$ & $\mathrm{R}^{\mathrm{b})}$ & $\mathrm{Cu}^{\mathrm{a})}$ & $\mathrm{R}^{\mathrm{b})}$ \\
\hline cotton & 12.0 & 5.11 & 29.0 & 0.19 & 32.8 & 0.38 \\
vinylon & 10.5 & over & 22.3 & 0.18 & 22.9 & 0.15 \\
\hline
\end{tabular}

a) Increment in weight after Cu-plating in $\mathrm{wt} \%$.

b) Electric resistivity in $\Omega /$ sq.
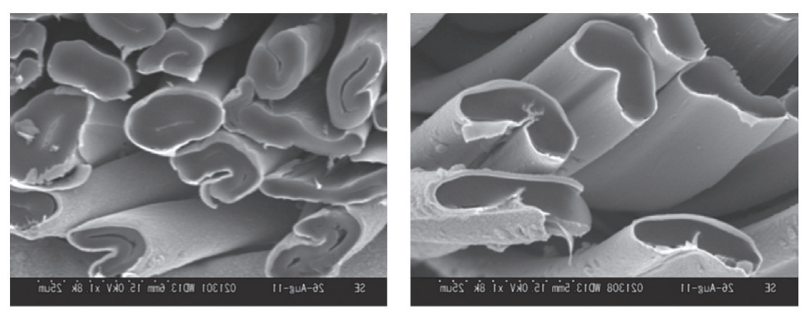
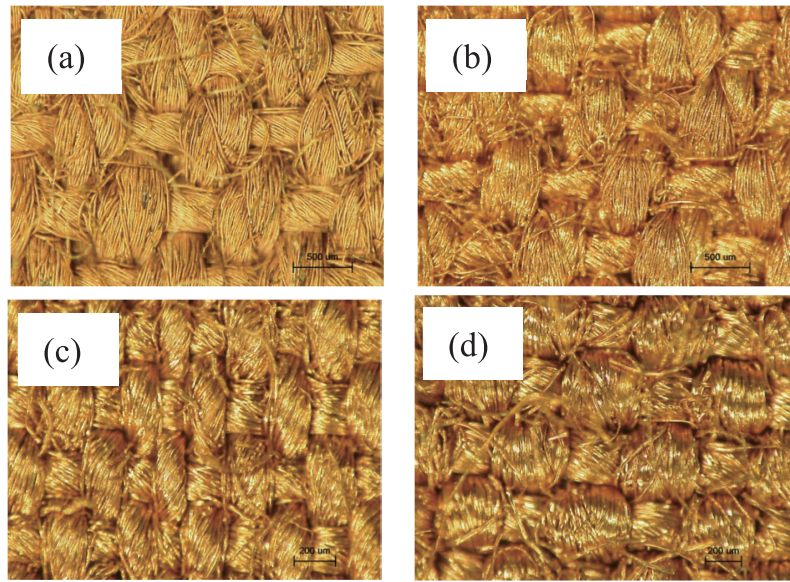

Fig. 12 Surface of Cu-plated fabrics after 10 times washing. (a) PP treated by $\mathrm{O}_{2}$ plasma and then $\mathrm{Cu}$ - plated, (b) PP treated by $\mathrm{O}_{2}$-plasma and APS and then Cu-plated, (c) cotton treated by APS and then $\mathrm{Cu}$ - plated and (d) vinylon treated by APS and then $\mathrm{Cu}$ - plated.

ものと思われる。それでも, これらの繊維が 10 回洗たく 後でもこれだけのめっきを保持していることは, 本手法 によるめっきの密着性がいかに高いかを示している.

\section{4. 結 論}

本研究ではシランカップリング剂が水酸基を有する繊 維と強固に結合することを利用し, 必要に応じてシラン カップリング剂の反応座席を設けるために酸素プラズマ も併用する新しい無電解めっき前処理法を検討した.

アミノ基を分子末端に有する 3 -アミノプロピルトリエ トキシシランを加水分解してシラノール誘導体とした後, これを 4 種の布帛に対して固定化した. PP と PET 布帛で は予め酸素プラズマ処理することで酸素原子を導入した もの, および十分量の水酸基を有する綿とビニロンに対 し， シラノール誘導体は固定することができた. シラノー ル誘導体の末端のアミノ基にはめっき触媒のPd が配位し, この強固な触媒付与により, 容易に無電解めっきができ た.

また,この方法で銅めっきした布帛は 10 回の洗たく後 も依然高い導電性を示した.

\section{文 献}

1. S. Sakka, "Development of Flourine Materials", (Japanese), CMC, Tokyo(1997).

2 S. Sakka, "Application of Sol-Gel Method" (Japanese), Agne Shofusha, Tokyo(1997).

3 K. Sattoh, H. Nakazumi, Textile Res. J., 741081 (2004).

4 Y. Yu, M.Z. Rong, M.Q.Zhang, Polymer, 51, 492 (2010).

Fig. 11 SEM images of cross section of $\mathrm{Cu}$-plated cotton (left) and vinylon fabric (right). 